\title{
Attitude of Dental Students for Personal and Professional Concerns about Rural Dental Practice
}

\author{
Susanthi R ${ }^{1}$, Lalchhuanawma², Sumit Gupta ${ }^{3}$, Maneesha Das $^{4}$, Vala Vikram Kumar ${ }^{5}$, Sreetama Chatterjee ${ }^{6}$, \\ Abhishek Singh Nayyar ${ }^{7 *}$
}

\section{Susanthi $\mathbf{R}^{1}$, Lalchhuanawma², Sumit Gupta ${ }^{3}$, Maneesha Das ${ }^{4}$, Vala Vikram Kumar ${ }^{5}$, Sreetama Chatterjee ${ }^{6}$, Abhishek Singh Nayyar ${ }^{7 *}$}

'Department of Public Health Dentistry, Anil Neerukonda Institute of Dental Sciences, Visakhapatnam, Andhra Pradesh, INDIA.

${ }^{2}$ Consultant Dental Surgeon, Selection Grade, Civil Hospital, Aizawl, Mizoram, INDIA.

${ }^{3}$ Formerly, Department of Conservative Dentistry and Endodontics, Sudha Rustagi College of Dental Science and Research, Faridabad, Haryana, INDIA. ${ }^{4}$ Department of Conservative Dentistry and Endodontics, Saraswati Dhanwantari Dental College and Hospital and Post-graduate Research Institute, Parbhani, Maharashtra, INDIA. ${ }^{5}$ Department of Conservative Dentistry and Endodontics, Department of Dentistry, Prathima Institute of Medical Sciences, Karimnagar, Telangana, INDIA.

${ }^{6}$ Department of Prosthodontics and Crown and Bridge, Santosh Dental College and Hospital, Ghaziabad, Uttar Pradesh, INDIA.

'Department of Oral Medicine and Radiology, Saraswati Dhanwantari Dental College and Hospital and Postgraduate Research Institute, Parbhani, Maharashtra, INDIA.

\section{Correspondence}

Dr. Abhishek Singh Nayyar

Department of Oral Medicine and Radiology, Saraswati-Dhanwantari Dental College and Hospital and Post-Graduate Research Institute, Parbhani- 431401, Maharashtra, INDIA.

Mobile no: +919850904067

Email: singhabhishekndls@gmail.com

History

- Submission Date: 22-05-2018

- Revised Date: 15-01-2019

- Accepted Date: 31-10-2019

DOI : 10.5530/ijmedph.2020.2.15

Article Available online http://www.ijmedph.org/v10/i2

\section{Copyright}

(C) 2020 Phcog.Net. This is an openaccess article distributed under the terms of the Creative Commons Attribution 4.0 International license.

\begin{abstract}
Context and Aim: The shortage of health professionals in rural areas contributes towards a discriminatory health care delivery. Accessibility of health services is a multidimensional concept that refers to geographical, economic (affordability), organizational and cultural (acceptability) factors that can facilitate and/or, hinder the use of services in rural areas. Oral health is an integral part of general health. Though highly preventable, oral diseases are the most common chronic diseases amongst all age groups. Furthermore, accessing dental services is particularly hard for people from the underserved and rural areas. Thus, the impact of dental care crisis has been and continues to be greater in rural areas. To add to this, paucity of dentists practicing in rural areas with the preference of dentists to locate their practices in urban areas does not bode well for the future of dental care for the rural population in the near future, too. Attitude of dental students plays an important role in determining the future dental work force in rural areas. With this background, the present study attempted to evaluate the attitude of dental students towards rural dental practice based on gender and year of education. Materials and Methods: The present study was based on a cross-sectional study design with 30-item questionnaire survey instrument employed and distributed amongst the undergraduate and postgraduate dental students. The questionnaire comprised of four parts including the first part which focused on information regarding the demographic details and opinion about the rural dental practice, the second part dealt with the professional concerns perceived regarding rural dental practice while the third and fourth parts dealt with the personal and general concerns of the dental students regarding the rural dental practice respectively. Anonymity and confidentiality of the respondents was given utmost importance while participation in the study was kept voluntary. Statistical Analysis Used: Statistical analysis was done using SPSS version 12.0 (SPSS Inc., Chicago, IL, USA). The said data was analyzed for descriptive and inferential statistics. Independent student's t-test and One Way Analysis of Variance (ANOVA) were used for comparison among the variables while chisquare test was used to determine association between the variables. The level of significance was set at 0.05. Results: From a total of 550 dental students, 428 respondents completed the questionnaire (Response Rate: $77.8 \%$ ). No significant difference was observed in the attitude of the students based on gender $(p=0.43)$ while a statistically significant difference was observed in the attitude of students based on the year of their education with a positive attitude towards rural dental practice generally noted in the first year Bachelor of Dental Surgery (BDS) students which significantly declined with the increasing level of education $(p=0.01)$. Conclusion: Dental students are more influenced by the negative aspects of rural dental practice though they have, in their mind, a positive approach for the same at the beginning of their education but this significantly declined with the increasing level of their education. Also, many dental students have a poor understanding of the fact what the term 'rural' actually means and of the rural health issues, in general. The present study, actually, adds to the understanding of the challenges that are faced by the dental professionals in rural dental practice.
\end{abstract}

Key words: Rural dental practice, World health organization, Census, Dental students, Attitude, Personal and professional concerns, Health care delivery, Educational and career advancement, Employment prospects for health professionals, Underserved and rural areas, Accessibility, Dental care crisis, Low-income countries, Health care community.

\section{INTRODUCTION}

Health workers are people engaged in actions whose primary intent is to enhance health. ${ }^{1}$ The world will be short of 12.9 million health care workers by 2035 with the same figure today being 7.2 million. A WHO report released recently warns that the findings, if not addressed now, will have serious

implications for the health of billions of people across all regions of the world in the future shortly. At present, the scarcity of health professionals and their inequitable distribution in urban and rural areas has been reported by many developing and even, developed countries. ${ }^{2}$ These shortages contribute to

Cite this article : Susanthi R, Lalchhuanawma, Gupta S, Das M, Kumar VV, Chatterjee S, Nayyar AS. Attitude of Dental Students for Personal and Professional Concerns about Rural Dental Practice. Int J Med Public Health. 2020;10(2):68-76. 
discriminatory health care delivery. Typically, from an Indian census point of view, rural has been defined with a 'deprivation' orientation, rural being a landmass without access to even the basic requirements of life including a continuous supply of electricity and water etc. ${ }^{3}$ Accessibility of health services is a multidimensional concept that refers to geographical, economic (affordability), organizational and cultural (acceptability) factors that can facilitate and/or, hinder the use of services in rural areas. ${ }^{4}$ Large metropolitan centers offer more opportunities for educational and career advancement, better employment prospects for health professionals and their family, easier access to private practice (an important factor in countries where salaries in the public sector are low) and lifestyle-related facilities and amenities while in most of the remote and underserved areas wherein health problems are more prominent, these opportunities are highly lacking with this being particularly true for low-income countries. ${ }^{5}$ In addition, the low status often conferred to those working in rural and remote areas further contributes to health professionals' preference for settling in urban areas where positions are perceived as more prestigious. ${ }^{6}$ Oral health is an integral part of general health. Microbial infections in the oral cavity affect the overall health status of an individual. In addition to diseases such as dental caries, a growing body of research suggests that poor oral health is linked to conditions such as type II diabetes, cardiovascular diseases, bacterial pneumonia and a plethora of other systemic diseases and complications including poor outcomes during pregnancy. ${ }^{7}$ Though highly preventable, oral diseases are the most common chronic diseases amongst all age groups. Furthermore, accessing dental services is particularly hard for people from the underserved and rural areas. Thus, the impact of dental care crisis has been and continues to be greater in rural areas. Dental care crisis involves issues or, concerns as the lack of adequate access to dental care in rural areas. This issue further gets complicated in the set-up which lacks appreciation for the significance of oral health care by other members of the health care community due to a lack of knowledge and/ or, inadequate realization of the importance of oral health care by the residents, especially, from the low income or, educational backdrops. ${ }^{8}$ To add to this, paucity of dentists practicing in rural areas with the preference of dentists to locate their practices in urban areas does not bode well for the future of dental care for the rural population in the near future, too. In India, the dentist to population ratio has been reported as 1:10,000 in urban areas and about 1:2,50,000 in rural areas. ${ }^{9,10}$ Attitude of dental students plays an important role in determining the future dental work force in rural areas. Moreover, the attitude to rural practice is multidimensional and can be broadly categorized based on the previous international research into professional concerns, personal concerns and general concerns as perceived by the health professionals. ${ }^{11-14}$ With this background, the present study attempted to evaluate the attitude of dental students towards rural dental practice based on gender and year of education.

\section{MATERIALS AND METHODS}

The present study was a descriptive, observational study which was based on a cross-sectional study design involving a 30-item questionnaire survey employed and distributed amongst 550 under- and post-graduate dental students who were enrolled in the present study via a randomized method wherein all the participants who agreed to participate voluntarily with a written informed consent were considered for the study. The research protocol was approved by the Institutional Ethics Committee and ethical clearance was obtained from the Institutional Review Board before the conduct of the study. The questionnaire comprised of four parts including the first part which focused on information regarding the demographic details and opinion about the rural dental practice, the second part dealt with the professional concerns (Item No.1-16) perceived regarding rural dental practice while the third and fourth parts dealt with the personal and general concerns (Item No.17-27) of the dental students regarding the rural dental practice respectively. The data obtained was, then, entered into excel sheets and subjected to statistical analysis. Anonymity and confidentiality of the respondents was given utmost importance and ensured for the obtainment of correct and unbiased results while participation in the study was kept voluntary.

\section{Statistical Analysis Used}

Statistical analysis was done using SPSS version 12.0 (SPSS Inc., Chicago, IL, USA). The said data was analyzed for descriptive and inferential statistics. Independent student's $t$-test and One Way Analysis of Variance (ANOVA) were used for comparison among the variables while chisquare test was used to determine association between the variables. The level of significance was set at 0.05 .

\section{RESULTS}

From a total of 550 dental students, 428 respondents completed the questionnaire (Response Rate: $77.8 \%$ ) while sixty seven respondents $(12.2 \%)$ were absent during the survey and fifty five respondents (10\%) returned incomplete questionnaire. Table 1 lists the demographic details of the respondents in terms of gender and the year of study which were the two most important criteria in knowing the attitude of the dental students towards rural dental practice. Table 1, also, highlights the general perception of the respondents in terms of the meaning they imply from the word 'rural' and the 'additional opportunities' they associate and assume in rural dental practice. More number of females (75.9\%) participated in the present study with the maximum number of response obtained from the students who were in their first year (19.9\%) of their professional education. The next, in order, were the second year (15.9\%) Bachelor of Dental Surgery (BDS) students while, the least number of responses came from the third year (10\%) students. The mean age of the respondents was $20.94 \pm 2.75$ years. $62.4 \%$ of the respondents considered 'distance, local facilities, type of people and the size of population' as the important determinants to describe a population 'rural' while $78 \%$ of the respondents believed both the 'community involvement and continuity of care' as the additional opportunities present in a rural scenario. Table 2 represents the comparison of dental students' attitude regarding professional concerns based on gender wherein a significant number of the female respondents (78.2\%) agreed that rural area provided numerous opportunities to practice a variety of skills while only $21.8 \%$ of the male respondents $(p=0.01)$ agreed that such opportunities are associated with rural practice. A significant positive attitude was noted amongst the female respondents $(70.3 \%)$ for the belief that there are good opportunities for employment for dental profession in the rural areas as compared to the male respondents $(29.7 \%)(p=0.03)$. Majority of female respondents $(80.7 \%)$, also, felt that staff is more supportive in rural areas while only $19.3 \%$ of the male respondents had a similar opinion $(p=0.004)$. Furthermore, $79.0 \%$ of the female respondents believed that rural dental practice offered more diverse working experience than as compared to an urban practice as against only $21.0 \%$ of the male respondents that has a similar opinion $(p=0.04)$. Longer working hours and poor working conditions were the major deterrents perceived by around $73.7 \%$ of the female respondents against rural dental practice which were, also, the reason cited by about $26.3 \%$ of the male respondents for why they did not want to opt for rural practice $(p=0.00) .71 .5 \%$ of the female respondents expressed worries about their future considering that entering into rural practice in early stages of their career could negatively impact status as a health practitioner in future. Likewise, $28.5 \%$ of the male respondents, too, had similar worry for their future and career advancement in their life ahead $(p=0.06)$. 


\begin{tabular}{|c|c|c|}
\hline \multirow{2}{*}{$\begin{array}{l}\text { Variable } \\
\text { Gender }\end{array}$} & \multicolumn{2}{|c|}{$\begin{array}{l}\text { No. of respondents } \\
n(\%)\end{array}$} \\
\hline & Male & $\begin{array}{c}103 \\
(24.1)\end{array}$ \\
\hline \multirow{8}{*}{ Year of study } & Female & $\begin{array}{c}325 \\
(75.9)\end{array}$ \\
\hline & I BDS & $\begin{array}{c}85 \\
(19.9)\end{array}$ \\
\hline & II BDS & $\begin{array}{c}68 \\
(15.9)\end{array}$ \\
\hline & III BDS & $\begin{array}{c}43 \\
(10.0)\end{array}$ \\
\hline & IV BDS & $\begin{array}{c}61 \\
(14.2)\end{array}$ \\
\hline & V BDS & $\begin{array}{c}60 \\
(14.0)\end{array}$ \\
\hline & Interns & $\begin{array}{c}50 \\
(11.7)\end{array}$ \\
\hline & PGs & $\begin{array}{c}61 \\
(14.3)\end{array}$ \\
\hline \multirow[t]{5}{*}{$\begin{array}{c}\text { What do you think as } \\
\text { 'rural'?? }\end{array}$} & Distance & $\begin{array}{c}24 \\
(5.6)\end{array}$ \\
\hline & Local Facilities & $\begin{array}{c}79 \\
(18.5)\end{array}$ \\
\hline & Type Of People & $\begin{array}{c}43 \\
(10.0)\end{array}$ \\
\hline & Size Of Population & $\begin{array}{c}15 \\
(3.5)\end{array}$ \\
\hline & All Of The Above & $\begin{array}{c}267 \\
(62.4)\end{array}$ \\
\hline \multirow[t]{4}{*}{$\begin{array}{c}\text { Additional } \\
\text { opportunities }\end{array}$} & Community Involvement & $\begin{array}{c}65 \\
(15.2)\end{array}$ \\
\hline & Continuity Of Care & $\begin{array}{c}29 \\
(6.8)\end{array}$ \\
\hline & Both & $\begin{array}{c}334 \\
(78.0)\end{array}$ \\
\hline & Total & $\begin{array}{c}428 \\
(100.0)\end{array}$ \\
\hline
\end{tabular}

A significant fact that was highlighted in the present study was that $71.1 \%$ of the female respondents assumed that remote and rural option prepares a student better for rural practice than urban practice while $28.9 \%$ of the male respondents, also, had a similar opinion $(p=0.007)$. Table 3 compares the attitude of dental students regarding professional concerns based on the year of education wherein $21.2 \%$ of the first BDS students presumed that working in a rural area provided more opportunity to practice a variety of skills whereas $21.6 \%$ of the interns disagreed with this statement $(p=0.01) .19 .1 \%$ of the post-graduates accepted the fact there are good opportunities for employment in rural areas in dental profession, a finding that went in contradiction with the first year BDS students wherein $22.6 \%$ of the students were not in acceptance of this fact $(p=0.07) .19 .1 \%$ of the first year BDS students accepted that rural dental practice provided greater opportunity for autonomy in work practice which was accepted by only $13.5 \%$ of the interns and $12.5 \%$ of the post-graduate students $(p=0.007)$. The study, on the contrary to the usual findings, found $20.5 \%$ of the first year BDS students worried that entering into rural practice in the early stages of their career could negatively impact their status as health practitioner whereas the maximum number of respondents from the same year were, also, found free from this negative fear (18.9\%) as compared to the respondents from the other years of the study. $16.0 \%$ of the postgraduate students and $10.7 \%$ of the interns, too, had similar fear for their career advancement and considered that entering into rural practice in the early stages of their career could negatively impact their status as health practitioner $(p=0.01) .19 .9 \%$ of the first year BDS students while $16.7 \%$ of the post-graduate students and $10.7 \%$ of the interns considered remote and rural option prepares a student better for rural practice than urban practice while a similar number of first year BDS students (19.8\%), also, disagreed with this statement $(p=0.07)$. Shockingly, $21.8 \%$ of the post-graduate students and $17.9 \%$ of the first year BDS students as well as an equal number of interns (17.9\%) had a fear that they will not be able to easily move from rural practice back to an urban practice highlighting the main fear why most of the dental professionals are reluctant to takeon with their rural postings, especially, on a long-term basis $(p=0.000)$. Table 4 gives an overview of the comparison of the attitude of dental students regarding the personal concerns based on gender and year of education wherein $21.4 \%$ of the first year BDS students considered people in rural areas were very friendly and that settling in rural areas was easy because of this $\left(p=0.001^{*}\right)$ while $18.2 \%$ of the first year BDS students and $17.5 \%$ of the post-graduate students, also, had a fear that working in rural settings carried a negative impact on spouse/children $(p=0.02)$. Likewise, poor recreational facilities was considered to be the major hindrance while free accommodation was considered to be a major advantage for working in a rural set-up and the results were, also, found to be significant, both, gender- and year-wise. Pair wise comparison of the attitude of dental students towards working and living in rural areas according to the year of education revealed significant differences in the personal concerns amongst the first year and fifth year students $(p=0.01)$ and interns with third $(p=0.002)$ and fifth year BDS students $(p=0.001)$. Similarly, significant difference in the attitude was noted for general concerns amongst the post-graduate students with third year $(p=0.01)$ and fifth year BDS students $(p=0.04)$. The Mean Attitude Scores for professional concerns amongst the male and female respondents were $60.7 \pm 14.1$ and $60.4 \pm 13.6$ respectively $(p=0.83)$. With regard to the personal concerns, the Mean Attitude Scores were found to be $61.6 \pm 14.1$ for male and $63.8 \pm 16.1$ for female respondents $(\mathrm{p}=$ $0.21)$. Likewise, no significant difference was noted for general concerns amongst the male and female respondents $(p=0.58)$. No significant difference was, thus, observed in the attitude based on gender $(p=0.43)$. Nevertheless, a significant positive attitude was noted amongst the first year BDS students towards rural dental practice as compared to the other years of education $(p=0.01)$.

\section{DISCUSSION}

Accessibility of health services is a multidimensional concept that refers to geographical, economic (affordability), organizational and cultural (acceptability) factors that can facilitate and/or, hinder the use of services in a given area. The quality and availability of specialist medical care, also, varies greatly amongst the different socio-economic groups and based on geographical distribution. Despite a high annual output of medical specialist graduates, specialist medical care has traditionally been very poor in India due to 'brain drain' or, the phenomena of highly educated Indians emigrating to western countries. ${ }^{9}$ The same scenario has been associated with dental professionals as well. Unsatisfactory 


\begin{tabular}{|c|c|c|c|c|c|}
\hline \multirow[t]{2}{*}{ Item No. } & \multirow[t]{2}{*}{ Professional Concerns } & \multicolumn{4}{|c|}{$\begin{array}{c}\text { Gender } \\
\text { n (\%) }\end{array}$} \\
\hline & & Response & Male & Female & $p$-value \\
\hline \multirow[t]{4}{*}{1.} & \multirow{4}{*}{ Working in a rural area provides more opportunity to practice a variety of skills. } & \multirow[t]{2}{*}{ Yes } & 77 & 277 & \multirow[t]{4}{*}{$0.01^{\star}$} \\
\hline & & & $(21.8)$ & $(78.2)$ & \\
\hline & & \multirow[t]{2}{*}{ No } & 26 & 48 & \\
\hline & & & $(35.2)$ & $(64.8)$ & \\
\hline \multirow[t]{4}{*}{2.} & \multirow[t]{4}{*}{ There are good opportunities for employment in rural areas in dental profession. } & \multirow[t]{2}{*}{ Yes } & 48 & 114 & \multirow[t]{4}{*}{$0.03^{*}$} \\
\hline & & & $(29.7)$ & $(70.3)$ & \\
\hline & & \multirow[t]{2}{*}{ No } & 55 & 211 & \\
\hline & & & $(20.7)$ & $(79.3)$ & \\
\hline \multirow[t]{4}{*}{3.} & \multirow[t]{4}{*}{ There are more opportunities for career advancement in rural areas. } & \multirow[t]{2}{*}{ Yes } & 30 & 93 & \multirow[t]{4}{*}{0.92} \\
\hline & & & $(24.3)$ & $(75.7)$ & \\
\hline & & \multirow[t]{2}{*}{ No } & 73 & 232 & \\
\hline & & & $(24)$ & $(76.0)$ & \\
\hline \multirow[t]{4}{*}{4.} & \multirow[t]{4}{*}{ Staff are more supportive to each other in rural areas. } & \multirow[t]{2}{*}{ Yes } & 50 & 210 & $0.004^{*}$ \\
\hline & & & $(19.3)$ & $(80.7)$ & \\
\hline & & No & 53 & 115 & \\
\hline & & & $(31.5)$ & $(68.5)$ & \\
\hline 5. & Rural dental practice provides greater opportunity for autonomy in work practice. & Yes & 79 & 253 & 0.80 \\
\hline & & & $(23.8)$ & $(76.2)$ & \\
\hline & & No & 24 & 72 & \\
\hline & & & $(25.0)$ & $(75.0)$ & \\
\hline 6. & Employment in rural areas is highly desirable. & Yes & 48 & 129 & 0.21 \\
\hline & & & $(27.3)$ & $(72.8)$ & \\
\hline & & No & 55 & 196 & \\
\hline & & & $(22)$ & $(78.0)$ & \\
\hline 7. & In rural areas, new people are welcomed into community. & Yes & 83 & 241 & 0.18 \\
\hline & & & $(25.7)$ & $(74.3)$ & \\
\hline & & No & 20 & 84 & \\
\hline & & & $(19.3)$ & $(80.7)$ & \\
\hline 8. & I think that practitioners working in a rural area are able to establish better & Yes & 67 & 204 & 0.67 \\
\hline & relations with their patients than practitioners working in urban areas. & & $(25.0)$ & $(75.0)$ & \\
\hline & & No & 36 & 121 & \\
\hline & & & $(23.0)$ & $(77.0)$ & \\
\hline 9. & I think that rural dental practice offers more diverse work experience than an & Yes & 60 & 224 & $0.04^{*}$ \\
\hline & urban practice. & & $(21.0)$ & $(79.0)$ & \\
\hline & & No & 43 & 101 & \\
\hline & & & $(29.8)$ & $(70.2)$ & \\
\hline 10. & I think rural dental practice offers more rewarding work than an urban practice. & Yes & 63 & 194 & 0.79 \\
\hline & & & $(24.51)$ & $(75.5)$ & \\
\hline & & No & 40 & 131 & \\
\hline & & & $(23.3)$ & $(76.7)$ & \\
\hline 11. & I think that financial rewards are higher for health practitioners working in an & Yes & 86 & 260 & 0.43 \\
\hline & urban rather than rural areas. & & $(24.9)$ & $(75.1)$ & \\
\hline & & No & 17 & 65 & \\
\hline & & & $(20.8)$ & $(79.2)$ & \\
\hline 12. & I think that rural practice entails longer hours and poorer working conditions & Yes & 66 & 263 & $0.00^{*}$ \\
\hline & than in urban practice. & & $(26.3)$ & $(73.7)$ & \\
\hline & & No & 37 & 62 & \\
\hline & & & $(27.4)$ & $(62.6)$ & \\
\hline
\end{tabular}


13. I am worried that entering into rural practice in early stages of career could negatively impact status as a health practitioner.

14. I feel that rural dental practice will be different to an urban dental practice. urban practice.

16. I am worried that I will not be able to easily move from rural practice back to an urban practice.

$\begin{array}{cccc}\text { Yes } & 50 & 125 & 0.06 \\ & (28.5) & (71.5) & \\ \text { No } & 53 & 200 & \\ & (20.9) & (79.05) & \\ \text { Yes } & 82(23.7) & 265 & 0.66 \\ & & (76.3) & \\ \text { No } & 21 & 60 & \\ & (25.9) & (74.1) & \\ \text { Yes } & 71 & 175 & 0.007 \\ & (28.9) & (71.1) & \\ \text { No } & 32 & 150 & \\ & (17.6) & (82.4) & \\ \text { Yes } & 41 & 115 & 0.41 \\ & (26.3) & (73.7) & \\ \text { No } & 62 & 219 & \\ & (22.8) & (77.2) & \end{array}$

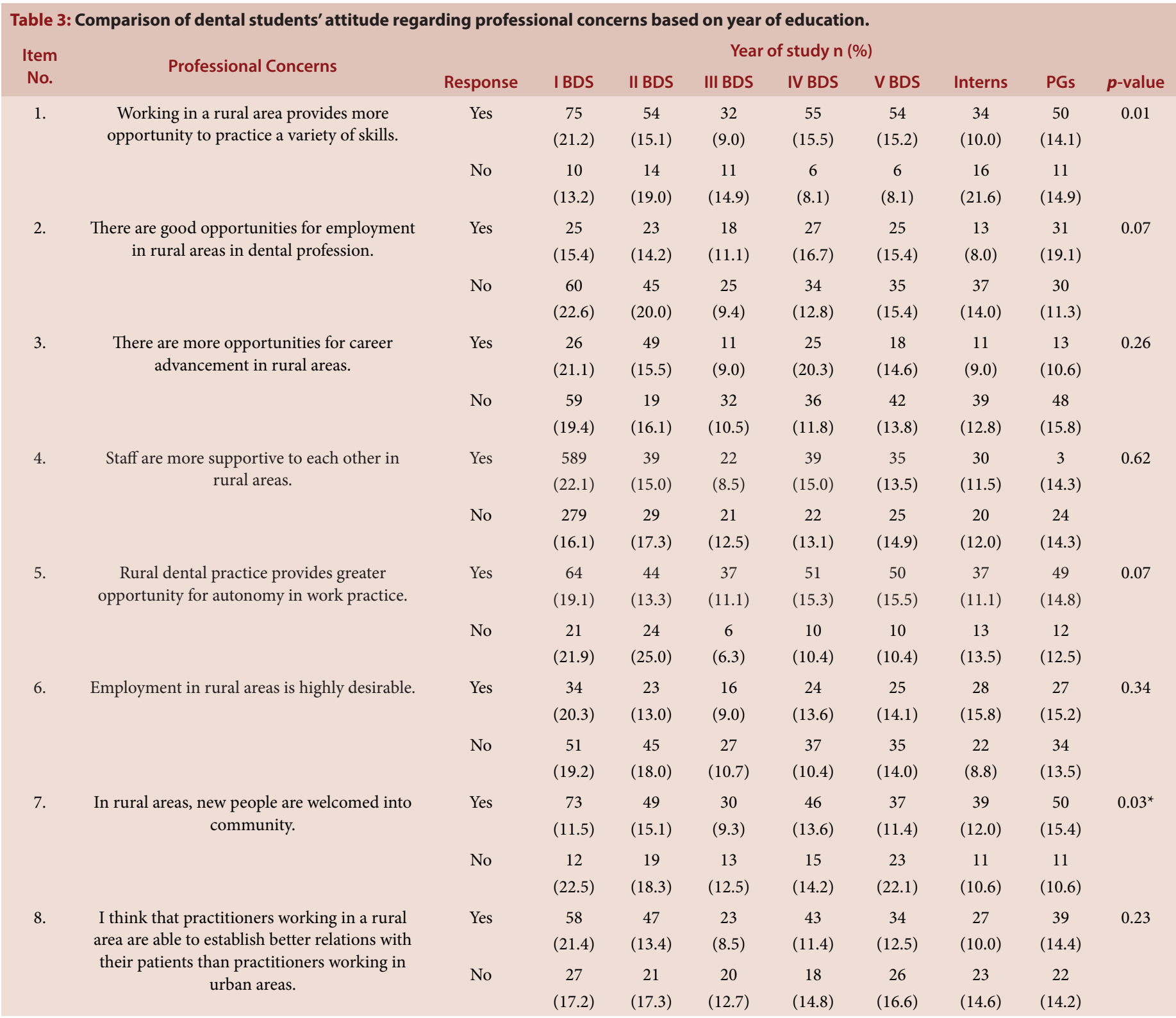




\begin{tabular}{|c|c|c|c|c|c|c|c|c|c|c|}
\hline \multirow[t]{2}{*}{9.} & \multirow{2}{*}{$\begin{array}{l}\text { I think that rural dental practice offers more } \\
\text { diverse work experience than an urban } \\
\text { practice. }\end{array}$} & Yes & $\begin{array}{c}59 \\
(20.8)\end{array}$ & $\begin{array}{c}42 \\
(18.1)\end{array}$ & $\begin{array}{c}26 \\
(9.2)\end{array}$ & $\begin{array}{c}42 \\
(13.2)\end{array}$ & $\begin{array}{c}40 \\
(14.9)\end{array}$ & $\begin{array}{c}35 \\
(12.3)\end{array}$ & $\begin{array}{c}40 \\
(14.1)\end{array}$ & \multirow[t]{2}{*}{0.90} \\
\hline & & No & $\begin{array}{c}26 \\
(18.1)\end{array}$ & $\begin{array}{c}26 \\
(14.8)\end{array}$ & $\begin{array}{c}17 \\
(11.8)\end{array}$ & $\begin{array}{c}19 \\
(13.6)\end{array}$ & $\begin{array}{c}20 \\
(13.9)\end{array}$ & $\begin{array}{c}15 \\
(10.4)\end{array}$ & $\begin{array}{c}21 \\
(14.6)\end{array}$ & \\
\hline \multirow[t]{2}{*}{10.} & \multirow[t]{2}{*}{$\begin{array}{l}\text { I think rural dental practice offers more } \\
\text { rewarding work than an urban practice. }\end{array}$} & Yes & $\begin{array}{c}61 \\
(23.7)\end{array}$ & $\begin{array}{c}45 \\
(17.5)\end{array}$ & $\begin{array}{c}19 \\
(7.8 .0)\end{array}$ & $\begin{array}{c}35 \\
(15.2)\end{array}$ & $\begin{array}{c}30 \\
(11.7)\end{array}$ & $\begin{array}{c}29 \\
(11.3)\end{array}$ & $\begin{array}{c}38 \\
(14.8)\end{array}$ & \multirow[t]{2}{*}{$0.03^{*}$} \\
\hline & & No & $\begin{array}{c}24 \\
(14.0)\end{array}$ & $\begin{array}{c}23 \\
(13.5)\end{array}$ & $\begin{array}{c}24 \\
(14.0)\end{array}$ & $\begin{array}{c}26 \\
(13.6)\end{array}$ & $\begin{array}{c}30 \\
(17.5)\end{array}$ & $\begin{array}{c}21 \\
(12.3)\end{array}$ & $\begin{array}{c}23 \\
(13.5)\end{array}$ & \\
\hline \multirow[t]{2}{*}{11.} & \multirow{2}{*}{$\begin{array}{l}\text { I think that financial rewards are higher for } \\
\text { health practitioners working in an urban } \\
\text { rather than rural areas. }\end{array}$} & Yes & $\begin{array}{c}68 \\
(20.7)\end{array}$ & $\begin{array}{c}55 \\
(16.0)\end{array}$ & $\begin{array}{c}35 \\
(10.1)\end{array}$ & $\begin{array}{c}47 \\
(17.1)\end{array}$ & $\begin{array}{c}51 \\
(14.7)\end{array}$ & $\begin{array}{c}40 \\
(11.6)\end{array}$ & $\begin{array}{c}50 \\
(14.4)\end{array}$ & \multirow[t]{2}{*}{0.96} \\
\hline & & No & $\begin{array}{c}17 \\
(19.6)\end{array}$ & $\begin{array}{c}13 \\
(15.9)\end{array}$ & $\begin{array}{c}8 \\
(9.1)\end{array}$ & $\begin{array}{c}14 \\
(16.1)\end{array}$ & $\begin{array}{c}9 \\
(11.0)\end{array}$ & $\begin{array}{c}10 \\
(12.2)\end{array}$ & $\begin{array}{c}11 \\
(13.4)\end{array}$ & \\
\hline \multirow[t]{2}{*}{12.} & \multirow{3}{*}{$\begin{array}{l}\text { I think that rural practice entails longer hours } \\
\text { and poorer working conditions than in urban } \\
\text { practice. }\end{array}$} & Yes & $\begin{array}{c}65 \\
(20.2)\end{array}$ & $\begin{array}{c}54 \\
(16.4)\end{array}$ & $\begin{array}{c}34 \\
(10.3)\end{array}$ & $\begin{array}{c}53 \\
(8.1)\end{array}$ & $\begin{array}{c}42 \\
(12.8)\end{array}$ & $\begin{array}{c}36 \\
(17.1)\end{array}$ & $\begin{array}{c}45 \\
(13.7)\end{array}$ & \multirow[t]{2}{*}{0.37} \\
\hline & & No & $\begin{array}{c}20 \\
(19.8)\end{array}$ & $\begin{array}{c}14 \\
(14.1)\end{array}$ & $\begin{array}{c}9 \\
(9.1)\end{array}$ & $\begin{array}{c}8 \\
(8.6)\end{array}$ & $\begin{array}{c}18 \\
(18.2)\end{array}$ & $\begin{array}{c}14 \\
(7.9)\end{array}$ & $\begin{array}{c}16 \\
(16.5)\end{array}$ & \\
\hline & & Yes & $\begin{array}{c}33 \\
(20.5)\end{array}$ & $\begin{array}{c}28 \\
(16.0)\end{array}$ & $\begin{array}{c}29 \\
(8.0)\end{array}$ & $\begin{array}{c}15 \\
(18.2)\end{array}$ & $\begin{array}{c}27 \\
(15.4)\end{array}$ & $\begin{array}{c}30 \\
(10.7)\end{array}$ & $\begin{array}{c}28 \\
(16.0)\end{array}$ & \multirow[t]{2}{*}{$0.01^{*}$} \\
\hline 13. & \multirow{2}{*}{$\begin{array}{l}\text { I am worried that entering into rural practice } \\
\text { in early stages of career could negatively } \\
\text { impact status as a health practitioner. }\end{array}$} & No & $\begin{array}{c}52 \\
(18.9)\end{array}$ & $\begin{array}{c}40 \\
(15.8)\end{array}$ & $\begin{array}{c}14 \\
(11.5)\end{array}$ & $\begin{array}{c}46 \\
(15.3)\end{array}$ & $\begin{array}{c}33 \\
(13.0)\end{array}$ & $\begin{array}{c}20 \\
(16.0)\end{array}$ & $\begin{array}{c}33 \\
(13.0)\end{array}$ & \\
\hline & & Yes & $\begin{array}{c}68 \\
(21.0)\end{array}$ & $\begin{array}{c}51 \\
(14.7)\end{array}$ & $\begin{array}{c}37 \\
(10.7)\end{array}$ & $\begin{array}{c}53 \\
(9.9)\end{array}$ & $\begin{array}{c}52 \\
(15.0)\end{array}$ & $\begin{array}{c}37 \\
(9.3)\end{array}$ & $\begin{array}{c}49 \\
(14.1)\end{array}$ & \multirow[t]{2}{*}{0.35} \\
\hline 14. & \multirow{2}{*}{$\begin{array}{l}\text { I feel that rural dental practice will be different } \\
\text { to an urban dental practice. }\end{array}$} & No & $\begin{array}{c}17 \\
(19.6)\end{array}$ & $\begin{array}{c}17 \\
(21.0)\end{array}$ & $\begin{array}{c}6 \\
(7.4)\end{array}$ & $\begin{array}{c}8 \\
(15.3)\end{array}$ & $\begin{array}{c}8 \\
(9.9)\end{array}$ & $\begin{array}{c}13 \\
(14.8)\end{array}$ & $\begin{array}{c}12 \\
(14.8)\end{array}$ & \\
\hline & & Yes & $\begin{array}{c}49 \\
(19.9)\end{array}$ & $\begin{array}{c}44 \\
(17.9)\end{array}$ & $\begin{array}{c}25 \\
(9.9)\end{array}$ & $\begin{array}{c}27 \\
(18.7)\end{array}$ & $\begin{array}{c}37 \\
(15.0)\end{array}$ & $\begin{array}{c}23 \\
(10.7)\end{array}$ & $\begin{array}{c}41 \\
(16.7)\end{array}$ & \multirow[t]{2}{*}{0.07} \\
\hline 15. & $\begin{array}{c}\text { The remote and rural option prepares a } \\
\text { student better for rural practice than urban } \\
\text { practice. }\end{array}$ & No & $\begin{array}{c}36 \\
(19.8)\end{array}$ & $\begin{array}{c}24 \\
(13.2)\end{array}$ & $\begin{array}{c}18 \\
(10.2)\end{array}$ & $\begin{array}{c}34 \\
(11.0)\end{array}$ & $\begin{array}{c}23 \\
(12.6)\end{array}$ & $\begin{array}{c}27 \\
(16.0)\end{array}$ & $\begin{array}{c}20 \\
(11.0)\end{array}$ & \\
\hline \multirow[t]{2}{*}{16.} & \multirow[t]{2}{*}{$\begin{array}{l}\text { I am worried that I will not be able to easily } \\
\text { move from rural practice back to an urban } \\
\text { practice. }\end{array}$} & Yes & $\begin{array}{c}28 \\
(17.9)\end{array}$ & $\begin{array}{c}17 \\
(10.9)\end{array}$ & $\begin{array}{c}12 \\
(11.4)\end{array}$ & $\begin{array}{c}16 \\
(16.6)\end{array}$ & $\begin{array}{c}21 \\
(13.5)\end{array}$ & $\begin{array}{c}28 \\
(17.9)\end{array}$ & $\begin{array}{c}34 \\
(21.8)\end{array}$ & \multirow[t]{2}{*}{$0.000^{*}$} \\
\hline & & No & $\begin{array}{c}57 \\
(21.0)\end{array}$ & $\begin{array}{c}51 \\
(18.8)\end{array}$ & $\begin{array}{c}31 \\
(7.7)\end{array}$ & $\begin{array}{c}45 \\
(10.3)\end{array}$ & $\begin{array}{c}39 \\
(14.3)\end{array}$ & $\begin{array}{c}22 \\
(8.1)\end{array}$ & $\begin{array}{c}27 \\
(9.9)\end{array}$ & \\
\hline
\end{tabular}

employment opportunities in various rural areas of India lead to migration of dental professionals to major cities and towns which disturbs the balance of the dentists population ratio., ${ }^{9,10}$ When access to dental services is limited by the shortage of dentists willing to work in rural areas, the attitude of dental students plays an important role in determining the future dental work force in rural areas offering benefits to the community. The present questionnaire-based study was designed keeping in mind this persistent worldwide problem of the shortage of health professionals in rural areas contributing towards a discriminatory health care delivery as found out based on the conclusions derived from the previous international research. ${ }^{11-14}$ The present study, actually, adds to the understanding of the challenges that are faced by the dental professionals in rural dental practice. The questionnaire used in the present study was tested for internal validity before the actual conduct of the study and was found to have a good internal consistency reliability with a Cronbach's alpha coefficient of 0.71 . The findings of the present study revealed that there was no significant difference in the attitude of dental students towards rural dental practice according to gender $(p=0.43)$. This was in contradiction with the results of a previous study conducted by Deaville JA et al. ${ }^{15}$ wherein females were found to be less likely than males to indicate a preference for rural practice. Based on the year of education, a statistically significant difference was observed in the attitude of students based on the year of their education with a positive attitude towards rural dental practice generally noted in the first year Bachelor of Dental Surgery (BDS) students which significantly declined with the increasing level of education $(p=0.01)$. This was in accordance with the findings of the previous studies conducted by Deaville JA et al. ${ }^{15}$ and Kaye DK et al. ${ }^{16}$ This significant difference in the attitude of dental students obtained in the present study and as could be found in the previous reported studies could be explained on the basis of limited prior exposure to rural health facilities and other associated factors. Overall, the perceptions of dental students in the present study about rural dental practice, at first glance, were not found to be encouraging. The said students appeared to have quite conventional and fixed viewpoints of what rural means based on distance, local facilities and type and size of population. From the findings of the present study, it was, thus, clear that many dental students have a poor understanding of the fact what the term 'rural' actually means and of the rural health issues, in general. The present study found that dental students were more influenced by the negative aspects of rural dental practice including the poor recreational facilities, longer working hours, poor working conditions, difficulty in moving back from rural to urban practice and the negative impact on spouse/children and career advancement, though, the study, also, highlighted the fact that dental students feel more attracted for towards 


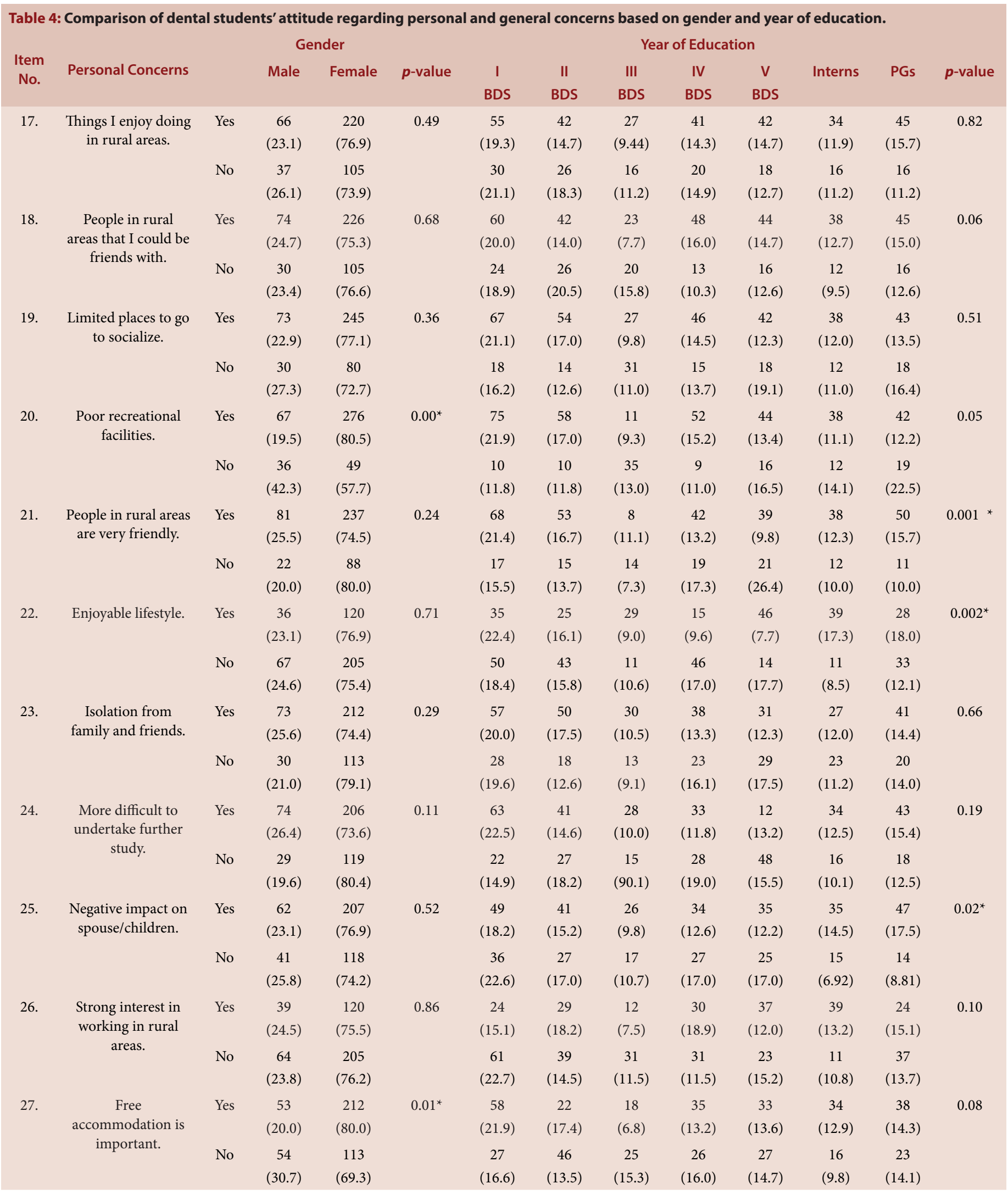

${ }^{\star}$ Statistically Significant 
the positive aspects of rural practice in the form of more diverse work experience and community support with kind people and staff in rural areas. This group of dental students actually expressed varied views on the relative merits and demerits of working in rural areas. The major factors that made dental students reluctant to work in rural areas included poor working conditions, difficulty in moving back from rural to urban practice and the negative impact on spouse/children and career advancement, though, the study, also, highlighted the fact that dental students feel more attracted for more diverse work experience and community support as the stronger positive aspects of working in rural areas. However, these diverse viewpoints did not make their approach highly convincing to work in rural areas in the end since most of the dental students, conclusively, considered rural practice largely unattractive in comparison with urban practice and did not prefer to work in the rural set-ups eventually. The viewpoints expressed in the present study were in accordance with the previous study conducted by Mullei K et al. ${ }^{17}$ A study conducted by Johnson GE and Blinkhorn AS, ${ }^{18}$ also, reported missing friends, partners and the number of available job opportunities as the major barriers perceived by students in New South Wales, Australia against working in rural areas. Likewise, the study conducted by Kotzee $\mathrm{TJ}$ and Couper ID $^{19}$ reported that professional development, ongoing training and style of health service management were the important factors influencing retention of health professionals in the underserved areas in a province from South Africa while similar findings in the form of low salaries and working conditions were found to be the major factors that discouraged public health workers in rural areas of North Viet Nam in the study conducted by Dieleman M et al. ${ }^{12}$ Another study conducted by Schofield D et al. ${ }^{20}$ that tried to find-out the preferable work areas amongst the health professional found that the decision to practice in a rural and/or, urban setting was governed largely as a result of a complex interaction between a number of factors including ethnicity, discipline, age, sex and type of work followed by career opportunities and the challenges faced. A plethora of studies have, also, noticed a strong relationship between a student's rural background and the student's subsequent intention to train and work in rural areas. ${ }^{11,21,22}$ Irane $\mathrm{AA}^{23}$ identified lack of essential equipment and non- availability of even basic resources like electricity, safe water and communication system apart from isolation from other units as important drawbacks hindering the health professionals to work in rural settings. Similarly, another study conducted by Lehmann $U$ et al..$^{24}$ found demanding working conditions, substandard medical equipment and facilities, inadequate financial remuneration, inadequate opportunities for personal and professional growth, safety concerns and lack of job opportunities for spouse and educational opportunities for children as the possible factors contributing to the reduced number of health care professionals in rural and urban underserved areas. Some experts like Khattak $\mathrm{FH}^{25}$ and others have, also, suggested probable remedies to this situation including establishment of rural health academies at divisional levels to impart training to the doctors working in the rural areas, priority in post-graduate education and training abroad for the said doctors, grant of rural and non-practicing allowance to the said professionals and regular linkages with administration, management and academic opportunities as the major concerns raised by the health professionals for working in rural areas. Similar viewpoint has been expressed by Kristiansen IS ${ }^{26}$ who advocated a proper education facility for the children of the doctors and staff working in rural areas as one of the priority requirements. $\mathrm{He}$, also, suggested the duty timings of a doctor to be fixed in a manner that they could easily take rest and perform their responsibilities efficiently apart from a provision of payment for overtime done by the said doctors, in case, the need arises for the same. Rosenberg $\mathrm{AM},{ }^{27}$ further, emphasized on the role the governments can take in using a combination of compulsory services and incentives to work in rural settings as the measures to improve the geographical distribution of health professionals. It has been suggested that a country's ability to retain health care professionals in rural areas ultimately depends upon the provision of a stable, rewarding and fulfilling personal and professional environment. Taking all these measures of differential rewards and provision of relief from the hardships involved, the health professionals might accept to work in rural areas providing solution to the discriminatory health care delivery in the rural backdrops which is a standing problem worldwide despite of the availability of health care resources in the present scenario.

\section{CONCLUSION}

The present study concluded that dental students were more influenced by the negative aspects of rural dental practice including the poor recreational facilities, longer working hours, poor working conditions, difficulty in moving back from rural to urban practice and the negative impact on spouse/children and career advancement, though, the study, also, highlighted the fact that dental students feel more attracted for towards the positive aspects of rural practice, too, in the form of more diverse work experience and community support with kind people and staff in rural areas. Furthermore, the present study, also, highlighted that most of the dental students had a positive attitude towards rural dental practice generally in the first year of their education but this significantly declined with the increasing level of their education. The present study, actually, adds to the understanding of the challenges that are faced by the dental professionals in rural dental practice. Furthermore, from the findings of the present study, it is clear that many dental students have a poor understanding of the fact what the term 'rural' actually means and of the rural health issues, in general. With this, most of the students considered rural practice largely unattractive in comparison with urban practice.

\section{ACKNOWLEDGEMENT}

To all the undergraduate and postgraduate dental students and interns who agreed to participate voluntarily in the present questionnaire survey based, descriptive, observational study and provided vital information regarding the professional and the personal and general concerns they have for rural dental practice and helped relentlessly during the conduct of this study as well as in the compilation of the data.

\section{CONFLICT OF INTEREST}

The authors declare no conflict of interest.

\section{ABBREVIATIONS}

WHO: World Health Organization; BDS: Bachelor of Dental Surgery.

\section{REFERENCES}

1. World Health Organization. The World Health Report 2006: Working together for health. World Health Organization, Geneva, Switzerland. 2019. http//www. who.org.

2. Boulle A. Rural health care and rural poverty- Inextricably linkedPolicy in progress. Health Systems Trust Update. 1997;28:6-7.

3. Department of Primary Industries and Energy and Department of Human Services and Health. Rural, remote and metropolitan areas classification. 1991 Census edition. Canberra, ACT: AGPS. 1994.

4. Frenk J. The concept and measurement of accessibility In: Health Service Research: An Anthology Edited by Washington, DC: Pan American Health Organization. 1992;858-64.

5. Chomitz K, Setiadi G, Azwar A. What Do Doctors Want? In Developing Strategies for doctors to serve in Indonesia's Rural and Remote Areas. Policy Research Working Paper no. 1888 Washington, DC: World Bank: 1998;1-43.

6. Zaidi A. Why medical students will not practice in rural areas: Evidence from a survey. Soc Sci Med. 1996;22(5):527-33. 
7. Xiaojing L, Kolltveit KM, Tronstand L, Olsend I. Systemic diseases caused by oral infection. Clin Microbiol Rev. 2000;13(4):547-58.

8. Rural Remedy. Alabama Rural Health Association. 2003;9:1-8.

9. Tandon S. Challenges to the Oral Health Workforce in India. J Dent Edu. 2004;68(7 Suppl):28-33.

10. Healthcare in India. Reports Highlights. Boston Analytics. 2009.

11. Richards L, Symon B, Burrow D, Chartier A, Misan G, Wilkinson D. Undergraduate student experience in dental service delivery in rural South Australia: An analysis of costs and benefits. Aust Dent J. 2002;47(3):254-8.

12. Dieleman $M$, Cuong $P V$, Anh LV, Martineau T. Identifying factors for job motivation of rural health workers in North Viet Nam. Hum Resour Health. 2003;1(1):10.

13. Eley D, Baker, P. Does recruitment lead to retention?- Rural clinical school training experiences and subsequent intern choices. Rural Remote Health. 2006;6(1):511.

14. Adams ME, Dollard J, Hollins J, Petkov J. Development of a questionnaire measuring student attitudes to working and living in rural areas. Rural Remote Health. 2005;5(1):327.

15. Deaville JA, Wynn-Jones J, Hays RB, Coventry PJ, McKinley RK, RandallSmith J. Perceptions of UK medical students on rural clinical placements. Rural Remote Health. 2009;9(2):1165.

16. Kaye DK, Mwanika A, Sekimpi P, Tugumisirize J, Sewankambo N. Perceptions of newly admitted undergraduate medical students on experimental training on community placements and working in rural areas of Uganda. BMC Med Educ. 2010;10:47.

17. Mullei K, Mudhune S, Wafula J, Masamo E, English M, Goodman C, et al. Attracting and retaining health workers in rural areas: Investigating nurses' views on rural posts and policy interventions. BMC Health Serv
Res. 2010;10(Suppl 1):S1.

18. Johnson GE, Blinkhorn AS. Student opinions on a rural placement program in New South Wales, Australia. Rural and Remote Health. 2011;11(2):1703.

19. Kotzee TJ, Couper ID. What interventions do South African qualified doctors think will retain them in rural hospitals of the Limpopo province of South Africa?. Rural Remote Health. 2006;6(3):581.

20. Schofield D, Fletcher S, Fuller J, Birden H, Page S. Where do students in the health professions want to work?. Human Resources for Health. 2009;7:7481.

21. Zina M, Daniels PT, Vanleit BJ, Skipper BJ, Sanders ML, Rhyne RL. Factors in Recruiting and Retaining Health Professional for Rural Practice. J Rural Health. 2007;23(1):62-71.

22. Dalton LM, Routley GK, Peek KJ. Rural Placements inTasmania: Do Experimental placements and background influence undergraduate health science student's attitudes toward rural practice?. Rural Remote Health. 2008;8(3):962.

23. Irane AA. Reforming Health Service Delivery at District Level In Ghana The Perspective Of A District Medical Officer. Health Policy And Planning. 1997:14(1):59-69.

24. Lehmann U, Dieleman M, Martineau T. Staffing remote rural areas in middleand low-income countries: A literature review of attraction and retention. BMC Health Serv Res. 2008;8(1):19.

25. Khattak FH. Health economics and planning in Pakistan. $3^{\text {rd }}$ Edition; Islamabad 1996. Original from The University of Michigan.

26. Kristiansen IS. Medical Specialist Choice of Location. The role of geographical attachment in Norway. Soc Sci Med. 1992;34(1):57-62.

27. Rosenberg AM. Ontario's Under Serviced Area Program Revisited: An Indirect Analysis. Soc Sci Med. 1990;30(1):35-44. 